\title{
O Problema dos Aquestos no Direito Civil Brasileiro
}

\author{
Élio Solon de Pontes \\ (Advogado)
}

\begin{abstract}
SUMÁRIO: I - Exposição do problema suscitado pelas interpretações diverǵntes do art. 259 do Código Civil; II - Argumentos favoráveis à tesej restritiva da comunhão dos aquestos aos regimes de separação convencional de bens; III - Tese contrária; IV - Tentativa de interpretaçäo sistemática do artigo em causa. Conclusão.
\end{abstract}

$\bigcup_{M}$ dos problemas interessantes de interpretação do Código Civil Brasileiro refere-se aos aquestos (1) no regime de separação de bens entre os cônjuges. Particularmente, pelos rumos divergentes da Jurisprudência em tôrno dêle.

Eminentes expressões das letras jurídicas pátrias já se voltaram para o art. 259 - fonte dêsse conflito doutrinário, - sem que se haja obtido, até agora, dissipação de dúvidas e desacôrdo, quanto à verdadeira exegese de tão importante dispositivo legal.

Enquanto o art. 258 consagra como regime legal, a "Comunhão universa!" ressalvados os casos do seu parágrafo único, em que é obrigatório o regime de separação de bens, o artigo seguinte é vazado nestes têrmos:

"Art. 259 - Embora o regime não seja o da comunhão de bens, prevalecerão, no silêncio do contrato, os princípios dela, quanto à comunicação dos adquiridos, na constância do casamento."

Em resumo: o regime legal, ou comum, no Brasil, no silêncio das partes, é o da comunhão universal, ressalvadas as importantes exceções relacionadas no parágrafo único do art. 258. Aplicando-se o mesmo princípio para os aquestos "no silêncio do contrato".

Ora, para que um regime conjugal deixe de obedecer aos preceitos do art. 258 ,duas hipóteses são necessárias:

1. ${ }^{\text {) }}$ Que haja contrato antenupcial dispondo em contrário (separação convencional, comunhão parcial e regime dotal, nêste de acôrdo com o art. 287, II);

(1) Bens adquiriơos, a qualquer título, por qualquer dos cônjuges, na constância da sociedade conjugal. 
2. ${ }^{\text {a) }}$ Que algum dos contraentes, ou ambos, estejam enquadrados em qualquer dos quatro incisos d) parágrafo único do referido artigo (separação obrigatória).

Vale dizer: ou pelo exercício da ampla autonomia de vontades, facultada no art. 256, ou em decorrência de taxativa proibição legal do regime de comunhão.

Essa distinção é importante, como veremos, para a rigorosa fixação do verdadeiro sentido do art. 259.

Êste, assim, começa: "Embora o regime não seja o da comunhão de bens", isto é, "embora o regime seja o da separação de bens, digamos, e.g. prevalecerão, quanto aos aquestos, os princípios dela, "no silêncio do contrato", isto é, salvo se, cláusula em contrário o dispuser, no contrato antenupcial, prevalecendo-se da liberdade de convencionar, amplamente facultada aos contraentes.

Admitamos, em face das dúvidas suscitadas pelo referido artigo, para maior clareza, e dentro do raciocínio acima, a seguinte redação para o artigo 259:

"A menos que, em contrato antenupcial, uma cláusula houver, estendendo aos aquestos, o regime da separação, prevalecerá, quanto a êsses bens o regime da comunhão."

Ressalvamos, entretanto, a hipótese especialíssima do regime de comunhão parcial (em que é característica a comunhão dos aquestos), ressalvada no inciso II, do art. 269.

Não cabendo qualquer restrição quanto ao regime dotal que, apesar de, tìpicamente, caracterizar-se pela separação de bens (PLANIOL, RIPERT e NAST, "Traité pratique de Droit Civil Français, 1927, vol 9, pág. 481 a 482-B e H. DE PAGE, "Traité Elémentaire de Droit Civil Belge, 1949, t. X, vol. 2, n. ${ }^{\circ} 14.088$, pág. 1.165) exceto quanto àquêles destinados expressamente "ad sustinenda onera matrimonii", que é o que nêle prepondera (RUGGIERo e MAROI - Instituzioni di diritto privato, vol. I, ed. 1949, § 59, pág. 248) não exclui, no sistema do Código Civil Brasileiro, a possibilidade de estipular, no próprio contrato que o estabelece, a coexistência de bens submetidos a regimes diversos (art. 287, II).

Duas são as interpretações do art. 259: a primeira entende que o mesmo só se aplica aos casos de regime convencional de separação e nunca aos de separação obrigatória; a segunda admite a sua aplicabilidade normal, sem distinções, a todos os casos.

Respeitáveis expressões das letras jurídicas pátrias filiam-se à primeira corrente, sendo bastante referir os exemplos de CarvalHo Santos e dos Ministros OROzIMBO NONATO e EDGARD COSTA que, com o vigor de admirável argumentação, vêm contribuindo para seu relativo prevalecimento.

Citam, aliás, tão eminentes membros do Colendo Supremo Tribunal Federal, opiniões de Américo de Oliveira CAstro e do Prof. ARnoldo de MEDEIRos. No mesmo sentido, manifestam-se, perante os Egrégios Tribunais de Justiça do Distrito Federal e de São Paulo, os desembargadores Hugo Auler e Pinto Do Amaral. 
Em sentido contrário, além do que se infere das observações de Clovis Bevilàqua, em seu "Código Civil dos Estados Unidos do Brasil, Comentado" (nota ao art. 259), manifestam-se, em votos perante o Supremo Tribunal $\mathrm{Fe}$ deral, os Ministros BarRos BarReto, LAFAyetTe DE ANDRAde, MACEdo LuDOLF e PHILADELPHO DE AzEVEDO, além de ilustres desembargadores aos tribunais de justiça de São Paulo e Distrito Federal, entre os quais Corderro Fernandes, Frederico Sussekind, Henrique Fialho e Homero Pinho.

Antes de tentar interpretação dêsse controverso artigo do Código Civil pátrio, vamos expor, justamente, os argumentos dos defensores de cada uma das teses.

Não podemos, entretanto, omitir uma terceira opinião em que não vemos senão uma exorbitância da verdadeira função jurisprudencial: a que admite sociedades de fato, entre os cônjuges, no regime de separação legal, provada a contribuição de ambos os cônjuges para cada um dos aquestos...

Respeitamos e mesmo, admiramos os argumentos com que se defende a tese "restritiva", ainda que, ao mesmo tempo, divirjamos das suas conclusões.

Mas não podemos concordar com a exigência ilegal de provas da combinação de esforços e de recursos, em cada caso, para que entrem na comunhão do casal, os bens adquiridos na constância do casamento, nos casos de separação "ex vi legis".

Porque discutir-se da necessidade ou não de provar "societas operarum" ou então de "societas rerum", em se tratando de sociedade conjugal, em que não tenha ocorrido separação de corpos ou desquite, seria admissível onde vigorasse diverso regime ou então nas alturas teóricas da doutrina; mas nunca no campo, limitado pela Lei, da verdadeira jurisprudência, a que repugna o risco do arbítrio judiciário. Verificaremos, entretanto, que êsse entendimento é geralmente aceito pela corrente restritiva, como válvula de escapamento para a pressão de argumentos contrários.

O preclaro Ministro EDGARD CosTA, a propósito da importante questão, depois de acentuar que o Supremo tem jurisprudência pró e contra a aplicabilidade do art. 259 aos casos de separação legal, ou obrigatória, "notadamente no de casamento de viuvos que o celebraram sem dar a inventário os bens do casal (art. 183, III)" fundamenta seu ponto de vista com estas citações:

"Na doutrina sobreleva, nessa interpretação, a douta opinião do Dr. Aimérico DE Oliveira CASTRo, no seu trabalho, sôbre "Regimes Matrimoniais."

"A primeira consideração - escreve êle - é que a lei alude, claramente, à idéia de contrato, quando diz: no silêncio do contrato, etc. Ora, o legislador não pode ignorar que a idéia fundamental do contrato é o acôrdo livremente consentido pelos contraentes, com pleno conhecimento de causa, para formarem um vínculo obrigatório. Onde não existe um acôrdo livre de vontades, expresso no conhecimento das partes, não existe contrato. Portanto, o art. 259, referindo-se ao silêncio do contrato, se refere, virtualmente aos casa- 
mentos em que há contrato ante-nupcial, exclusivo da comunhão geral. O regime de separação de bens obrigatória, aberrando de modo flagrante, do conceito básico de todo contrato, exclui de modo absoluto a sua inclusão na fórmula do artigo 259, tão sòmente aplicável no silêncio do contrato. Em segundo lugar, seria ilusório e ridículo o caráter coercitivo que emana evidentemente das medidas consignadas no Código Civil, art. 258, parágrafo único, se a separação obrigatória não fôsse extensível aos bens futuramente adquiridos pelos cônjuges. Finalmente, o art. 258, parágrafo único, não distingue quais os bens, se presentes tão sòmente, ou se presentes e futuros que incidem na separação obrigatória; ora é regra de interpretação que "ubi lex non distinguit nec nos distinguere debemus" (pág. 289).

Acorde com essa inteligência do art. 259, está o Dr. Carvalho Santos em seus "Comentários ao Código Civil', vol. V, pág. 55: "O legislador ao dispor pela forma que o fêz, pressupõe a existência de um contrato ante-nupcial. $\mathrm{E}$, sòmente quando o contrato silen-. cie, manda que se aplique o dispositivo supra..." (Supremo Tribu-

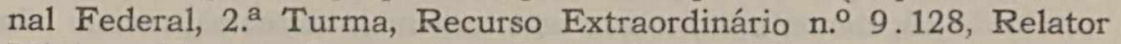
Ministro EDGARD Costa, Acórdão de 23-5-1947).

Por sua vez, o Ministro Orozimbo Nonato, uma das mais vigorosas culturas jurídicas brasileiras da atualidade, manifesta-se com estas palavras:

"No regime convencional de separação de bens, comunicam-se os adquiridos, salvo expressão contrária dos cônjuges; mas, no legal, e quando a separação traduz a reação da lei contra infração de seus preceitos, a extensão é maior, abrange os aquestos, sem o que se apagaria o caráter punitivo da lei que ordena a separação".

"Inaplicável é, assim, no caso, o art. 259 do Código Civil que, declaradamente, prevê, apenas, a hipótese da separação convencional. Se a separação é decretada pela lei em preceito inserto entre "disposições peiıais" (art. 226, cap. VII, do Código Civil), ela não se equipara à separação convencional e nem autoriza a comunicação dos adquiridos, o que valeria por abrandamento da pena, suscitada, não pelo legislador, se não pelo intérprete, por argumento a pari incabível por faltar o extremo da "identidade de motivos" ou "semelhança de razão".

"A separação imposta por fôrça de lei não é parcial, senão absoluta. Nem vale derivar a questão para o reconhecimento, aceito por numerosos arestos, de comunhão de bens adquiridos pelo esfôrço comum do casal de estrangeiro com brasileira. Não concorri com o meu modesto voto para essa jurisprudência que, de resto, examina em cada espécie o fato de grangeio dos bens pelos cônjuges. Possível é que ocorra, então, uma sociedade ex factis et rebus; mas essa sociedade não se confunde com a comunhão conjugal, que é sui ǵeneris e tem características próprias que a extremam da sociedade."

(Supremo Tribunal Federal, Plenário, Relator Ministro OROzimbo Nonato, Acórdão de 8-11-1948). 
E interessante salientar que, justamente confirmando, em sessão plenária, o julgamento do Recurso Extraordinário n. ${ }^{\circ}$ 9.128, a que aludimos, e o voto em que o mesmo se baseou, de autoria do Ministro EdGard Costa, coube ao Ministro OROzIMBo NoNATo reafirmar o seu ponto de vista com os seguintes argumentos:

"O fim da lei foi eliminar a influência de interêsses patrimoniais no casamento de pessoas idosas. E êste fim seria iludido se vigorasse para os aquestos conjugais o regime da comunhão de bens."

Além dêste argumento, que me parece muito persuasivo, é também de ponderar-se que o art. 259, se não tem caráter punitivc; temno coercitivo e tutelar. Naturalmente, a lei não vai punir a inclinação amorosa de pessoas de idade avançada. São casos, algumas vêzes dolorosos, de amores crepusculares, que dão matéria a dramas e romances; nêles, porém, o legislador não se imiscui. O a que êle visa é defender essas pessoas de idade da influência de pessoas mais moças, da sedução, a que estariam mais expostas, muitas vêzes já nos cancelos do túmulo e nos clarões derradeiros de sua vida.

Ora, se a lei quer proteger o sexagenário, determinando que não se estabeleça a comunhão de bens em seu casamento, essa proibição seria frustrada se não alcançasse os aquestos que, muitas vêzes, derivam de bens já anteriormente possuidos, por natural incremento e valorização.

Ao argumento de que, no caso, ficaria a mulher, que trabalhou na constância do casamento, privada de recursos, pode-se responder que a jurisprudência admite uma sociedade ex factis et rebus, uma sociedade de fato, a fim de atenuar essa circunstância. Se a mulher provar que êsse enriquecimento decorre também de seu esfôrço, que existe, no caso concreto, uma sociedade de fato, a comunhão se estabelecerá, até o limite dêsses esforços, e sem caráter de regime de bens no casamento."

(Supremo Tribunal Federal, Sessão Plenária, Rec. Extr. número 9.128, Relator Ministro Orozimbo Nonato, Acórdão de 5-101949).

Ainda ressaltando o pressuposto de contrato ante-nupcial, como condição necessária para a aplicação da regra do art. 259, assim se manifesta o Desembargador Hugo AuLER no Tribunal de Justiça do Distrito Federal.

"Reconhecido "ex-vi-legis" o regime da separação de bens, por fôrça do disposto no art. 258, parágrafo único, do Código Civil, não se há de aplicar a qualquer dos cônjuges a regra de que, no silêncio do contrato, é facultada a comunicação dos bens adquiridos na vigêricia do casamento, pois tal dispositivo excepcional presupõe a existência de um contrato ante-nupcial em que tenha sido silenciada a questão dos adquiridos durante as segundas núpcias. Se o regime de 
bens resulta de expresso texto legal que estabelece uma sanção penal, nenhuma restrição poderá ser oposta à aplicação do princípio de ordem pública que determina a mais completa separação de bens. Nem seria lógico admitir-se a comunicação dos aquestos, quando a lei proíbe que o cônjuge culpado faça ao outro doações; se dá como garantia aos filhos do primeiro leito hipoteca legal sôbre os bens dos pais que contraem segundas nupcias antes de fazer o inventário dos bens de seu primeiro casamento."

(Tribunal de Justiça do D. Federal, Apelação n. ${ }^{\circ}$ 11.304. Relator: HUgo AUler, ac. 8-1-52).

E curioso notar que, em 1951, confirmando sentença de magistrado paulista - Dr. Vicente Sabino JunIor, aliás, favorável à comunhão dos aquestos, no regime legal de separação de bens, o Desembargador PINTo Do AMARAL, depois de assinalar os rumos contraditórios da jurisprudência pondera:

"É preciso não esquecer que se cogita de separação modificável pela convenção ante-nupcial; em se tratando de separação absoluta, como a do caso do art. 258, a vontade dos contraentes jamais a modificará. Assim, a regra do art. 259, como ficara assinalado, não se aplica a tais casos. Trata-se, mesmo, de preceito de ordem pública, inalterável pela vontade popular. PLANIOL, ("Traité Élémentaire", $1 .^{\circ}$, n. $^{\circ} 228$ ) escreveu, com relação ao respeito devido aos limites traçados pela lei, que "la liberté est la règle; la volonté privée est autonome, sauf les limites fixés par la loi. Il suffira donc d'indiquer ces limitations légales."

(Cf. "Ementário Forense", abril, 1953, n. ${ }^{\circ}$ 53).

Parece-nos, diante de argumentos tão claramente expostos pelos defensores dêssse ponto de vista, oportuno sintetizá-lo numa redação adaptada do art. 159, que seria, assim, apresentada:

"Embora o regime não seja o da comunhão de bens quando houver contrato antenupcial e não se dispuser, nêle, expressamente, em contrário, prevalecerão, quanto aos aquestos, os princípios daquêle."

Esta corrente se caracteriza, portanto pela ênfase que atribui a quatro palavras do art. 259 que são "no silêncio do contrato"; e, além disso, pelo zêlo marcante dessa exegese com os casamentos celebrados nos casos previstos no parágrafo único do art. 258, especialmente o inciso II.

Justifica-se tal cuidado? Será verdadeiro o pressuposto da existência de contrato escrito como condição "sine qua non" da aplicabilidade do preceito contido no art. 259 do Código Civil.

E o que, depois de alinhar os argumentos da "tese ideal" (na denominação de AUlus Plautius MACEDO) tentaremos responder.

Antes, portanto, examinemos êsse ponto de vista. 


\section{III}

Em julgado de 19 de maio de 1949, sendo relator o Desembargador J. BARbosa DE Almeida, o Tribunal de Justiça de São Paulo, por sua 3. ${ }^{a}$ Câmara, confirmando sentença do Juiz Hugo CACCURI, depois de afirmar que, está, definitivamente, assentada a tese do reconhecimento da sociedade de fato, ou comunhão de interêsses, "nos casos de separação legal, invoca a autoridade do insigne Costa Manso, em voto perante o Colendo Supremo Tribunal Federal, com esta citação:

"... adquiriam os cônjuges bens, neste país, com o fruto do trabalho e da economia de ambos. Não há razão para que tais bens fiquem pertencendo, exclusivamente, ao marido. Não é de presumirse que só o marido ganhe dinheiro e possa adquirir bens. Nas famílias pobres a mulher trabalha e aufere recursos pecuniários, havendo casais em que só ela sustenta a família."

O homem não pode ter a parte do leão. Ora, os bens resultantes dêsse esfôrço comum são bens comuns. $\mathbf{E}$ não se podendo estabelecer a percentagem que nêles deva ter cada um dos cônjuges, entende-se que a cada um cabe a metade. E a regra de direito, consagrada no art. 1.376 do Código Civil quanto às sociedades. No silêncio do contrato presumir-se-ão iguais entre si as entradas. Nas sociedades de fato ou comunhões de interêsses não é outro o princípio a aplicar. ("Revista dos Tribunais", vol. 118, pág. 256).

Por sua vez, o Ministro LAFAyetTe de ANDRAdE conforme se lê no fascículo 542, de agôsto de 1948, da "Revista Forense", em voto vencido, por ocasião do julgamento do Recurso Extraordinário n. ${ }^{\circ} 9.128$, procedente de Minas Gerais, a que já nos referimos, assim raciocina:

"Se a lei admite comunhão dos adquiridos na constância do casamento, quando há contrato estabelecendo o regime de separação, não vejo motivo ponderável para afastar essa comunhão quando a separação é determinada por lei."

Depois de, assim, negar caráter diferencial à causa, se a conseqüência, a rigor, é a mesma - o regime de separação, cita, ainda o ilustre julgador, uma das razões de PHILAdelpho DE AzeVEDo para esposar idêntica doutrina: a de que se inclina êle para a extensão da regra "em face da tradição do nosso direito, cada vez mais firme no sentido da comunhão".

Contraditando o argumento de que o art. 259 pressupõe contrato antenupcial o Desembargador Sílvio Martins Teixeira, perante a $4 .{ }^{a}$ Câmara do Egrégio Tribunal de Justiça do Distrito Federal, observa:

"Como argumenta o Dr. Procurador Geral, "quando o contrato não dispõe a respeito de forma diversa ou, "a fortiori", quando contrato não houver, os aquestos se comunicam". (Revista Forense, vol. 145 , pág. 253 ). 
Outro aspecto altamente esclarecedor se evidencia de brilhante relatório do Desembargador Frederico SusseKind perante a $6^{a}$ Câmara do Tribunal de Justiça do Distrito Federal, no Agravo de Instrumento n. ${ }^{\circ} 2.035$. A hipótese gravitava em tôrno de orfã de pai e mãe (inciso III, do parágrafo único, do art. 258), sendo os seguintes os pontos principais da peça:

"Falecendo o marido e deixando bens, êstes, adquiridos na constância do casamento, poderão ser admitidos como comuns do casal, a serem partilhados, metade por metade?"

- Entendeu o ilustrado Juiz Dr. Xenócrates Calmon DE AGUIAR, na decisão que se confirma, afirmativamente, por ter ocorrido a comunhão dos aquestos, de acôrdo com o pensamento do autor da emenda em que se consubstanciou o citado dispositivo legal visando a proteção do órfão ao se casar, e não penalidade futura, a que não podia merecer, além de que o art. 259 reconhece a comunhão mesmo no regime de separação convencional."

Aludindo à resistência do $4 .^{\circ}$ Curador de Órfãos e do $10^{\circ}$ Subprocurador Geral conclui o Desembargador SusSEKIND:

"Esta Câmara tem seu ponto de vista já firmado em outras decisões, no sentido do afirmado pela sentença agravada, dentro do ensinamento do saudoso e insigne Ministro PHILADELPHO DE AzEVEDo, de que a exigência da separação foi para evitar, no momento do casamento, a confusão dos patrimônios; nada, portanto, se oporia a que, de futuro, pelo esfôrço conjunto dos cônjuges, o patrimônio alargasse e abrangesse todos os bens adquiridos. Nesse sentido é a jurisprudência do Egrégio Supremo Tribunal Federal."

(CF. "Revista de Jurisprudência Brasileira", vol. 94, fasc. 280281 , pág. 59 , ano 1952 ).

Pela mesma orientação se tem pronunciado o Tribunal de Justiça de São Paulo, como se pode verificar dos trechos, a seguir transcritos, do relatório do Desembargador Alceu CoRdeiro Fernandes, na qual vemos, ainda uma vez, invocada a autoridade do Ministro PhILAdelpho DE Azevedo, mercê dos esclarecidos argumentos com que veio robustecer a corrente que esposou, e que, inicialmente, aliás, careceu, precisamente, de fundamentação mais acatável, sólida e persuasiva para que viesse a predominar.

Diz o magistrado paulista:

"Como bem pondera Philadelpho de Azevedo, o nosso sistema de separação de bens, em princípio, é o da separação dos existentes e de comunhão dos bens adquiridos, sendo indispensável cláusula expressa, no pacto antenupcial, para que a separação se estenda aos aquestos" (Um Triênio de Judicatura", vol. I, pág. 308).

- Nem seria jurídico e justo, inexistindo disposição especial acêrca dos bens adquiridos, consagrar o aniquilamento de princípio fundamental de direito, qual seja o de que a ninguém é lícito locupletar-se com o trabalho alheio. 
- Aliás, a finalidade da exceção do parágrafo único do art. 258 do Código Civil, foi, sem dúvida, criar obstáculos à ambição, à cobiça dos que, olvidando os legítimos objetivos do matrimônio, a êle se apegam com interêsses inferiores.

- A Lei não poderia visar, portanto, os bens futuros adquiridos na constância do casamento, com a participação de ambos os cônjuges.

- Na hipótese, como bem assinalou o aresto embargado, dois dos imóveis foram adquiridos na constância do casamento da autora e não há motivo para supor que ela, com seus esforços, com a sua economia no lar, não haja concorrido para amealhar os recursos com que tais aquisições foram feitas."

(Revista dos Tribunais, abril de 1954, vol. 222, pág. 158, julgado em 3-11-1953).

Nas transcrições acima figuram os principais argumentos sôbre os quais se apoia a tese em exame.

Referir-nos-emos, entretanto, como último exemplo, especialmente para espelhar, aqui, o sentido da jurisprudência, um julgado do Tribunal de Justiça do Distrito Federal em que o eminente Desembargador Henrique FialHo como relator da Apelação n. ${ }^{\circ} 12.087$, perante a $6{ }^{a}$ Câmara do Distrito $\mathrm{Fe}$ deral, limita-se, de forma peremptória, a dizer-se favorável a concessão de provimento a recurso, nos têrmos de parecer do Dr. Procurador Geral, para reformando sentença apelada, reconhecer à interditanda o direito à meiação dos bens adquiridos na constância de casamento, contraído pelo regime de separação de bens "ex-vi" do disposto no parágrafo único, n. ${ }^{\circ}$ I, do art. 258 , do Código Civil, explicando que o faz,

"não só èm conformidade com anteriores decisões desta mesma Câmara, em casos idênticos, como ainda em conformidade com jurisprudência do Egrégio Supremo Tribunal Federal, citado no referido parecer.

(Arquivo Judiciário, vol. CIV, pág. 231, novembro de 1952).

Diante do acima exposto, permitimo-nos sintetizar a interpretação considerada na seguinte fórmula:

"Art. 259 - (adaptação). Se não houver em contrato antenupcial, cláusula proibitiva, prevalecerão, quanto aos aquestos, os princípios da comunhão, embora diverso fồ o tegime."

Tendo o cuidado fundamental de PAULO - "Non ex regula jus sumatur, sed ex jure, quod est, regula fiat" (não seja extraída, da regra, o Direito, mas, elaborada a regra de acôrdo com o que o Direito o é), vamos, entretanto, com a máxima fidelidade aos preceitos da hermenêutica, tentar fixar os limites precisos da aplicabilidade do art. 259 do Código Civil Brasileiro, ou seja, no papel de que nos fala o eminente CARLos MAXIMILIANo (uma das glórias supremas 
da cultura jurídica nacional), "de dar vida aos textos, fazê-los eficientes em tôda sua plenitude", diligenciando por "revelar, não só o sentido, mas também o alcance integral dos mesmos".

Porque, diz Celso, "scire leges non est verba earum tenere, sed vim ac potestatem" (conhecer a lei não é apreender, meramente, suas palavras, mas seu espírito e alcance).

Para isso, atentaremos para a interpretação literal, que saberemos insufi.. ciente: "littera occidit; spiritus, autem, vivificat". Contrastá-la-emos, a seguir, com a interpretação lógica. E, por fim, mediante a interpretação sistemática, compararemos os resultados com dispositivos co-relacionados, encerrando, com apoio nos preceitos usuais que orientam o hermeneuta o ciclo interpretativo que, como o salienta o eminente professor Matos Peixoto, se compõe justamente, do conjunto dêsses "momentos ou estádios" (José Carlos DE MATOS Peixoto) - "Curso de Direito Romano", 2. a Ed., n. o 122, pág. 192).

Analisemos, pois, o artigo em causa.

Fixemo-nos, inicialmente, nestas duas idéias capitais do texto considerado: "Embora o regime não seja o da comunhão de bens" (1) e "no silêncio do contrato".

A primeira é, evidentemente, característica de um preceito geral. Importa em referência genérica, mas inequívoca, a todos os regimes: exclusive, tão sòmente, o da comunhão parcial, em face do preceito contido no inciso II, do art. 269. Porque, neste caso, a "declaração dos contraentes" a que se refere o art. 269 há que ser entendida como exclusão dos "adquiridos com valores exclusivamente pertencentes a um dos cônjuges, em subrogação dos bens particulares".

Parece-nos acertado êsse amplo sentido, tanto mais quando se considera que êle se aplica, inequivocamente, ao regime da separação de bens e ao regime dotal.

Neste último caso, Clóvis Bevilaqua, ao comentar o art. 280 do Cod. Civil, lembra ser "indispensável declaração expressa referente aos bens que ela (a mulher) venha a possuir por herança ou doação". E aduz: "a especificação e estimação dos bens futuros serão feitas à medida que êles entrarem para o patrimônio da dotada. Sem essas formalidades serão os bens comuns, por isso que não haverá no contrato matrimonial indicação de outro destino".

Quanto à "separação obrigatória", seria de excluí-la, quanto aos aquestos, da regra estabelecida no art. 259? Trata-se de artigos justapostos, vizinhos, em que aparente conflito se dissipa, com o seguinte raciocínio: é verdade que o parágrafo único do art. 258, para certos casos, determina, obrigatòriamente, o regime de separação de bens mas, não menos verdade é que no artigo seguinte, preceitua que independentemente do regime, vigorarão os princípios da comunhão universal quanto aos aquestos... "no silêncio do contrato".

Por que "no silêncio do contrato"?

Qual o verdadeiro alcance desta expressão?

A interpretação "clássica" (a denominação é de Aulus MACEDo) é baseada num pressuposto de contrato em certo sentido jurídico, disto resultando a exclusão da "separação legal", do princípio da comunhão dos aquestos. 
Contràriamente, é de supor-se que o legislador, não quisesse restringir aos casos de casamento por contrato expresso, o regime legal de comunhão dos aquestos, mas dizer, tão sòmente, "que cláusula expressa seria exigível aos. que pretendessem dela esquivar-se".

"No silêncio do contrato" significaria o mesmo que "salvo se cláusula. contratual dispuser em contrário".

Verdade é que, se bem examinarmos os quatro incisos do art. 258, concluiremos que nem sempre seria impossível aos contraentes, nas hipóteses consideradas, exteriorizar o desejo de separação dos aquestos.

Entretanto, (mesmo se assim não acontecesse), a consequiência emergente não seria indesejável: "nos regimes de separação obrigatória de bens, aplicarse-á, quuanto aos aquestos, o regime da comunhão".

Impõe-se-nos, entretanto, focalizar as várias classes em que se dá a separação legal, para que se evidencie a propriedade ou a impropriedade dos argumentos expostos com base nêles.

A primeira classe é o das pessoas que celebrarem casamento com infração do estatuído no art. 183, ns. XI e XVI ou seja:

a) "XI - Os sujeitos ao pátrio poder, tutela, ou curatela, enquanto não obtiverem ou não lhes fôr suprido o consentimento do pai, tutor, ou curador", caso em que qualquer um dêstes pode requerer a anulação do casamento.

b) "XII - As mulheres menores de dezesseis anos e os homens menores de dezoito" - casamento êste anulável, exceto quando permitido para evitar imposição ou cumprimento de pena criminal, podendo o Juiz, ordenar a separação de corpos até que os cônjuges alcancem a idade legal.

c) "XIII - O viúvo ou a viúva que tiver filhos do cônjuge falecido, enquanto não fizer inventário dos bens do casal e der partilha aos herdeiros".

Pelo art. 225, o viúvo ou a viúva que se casar nas condições acima perderá o direito ao usofruto dos bens dos mesmos filhos.

d) "XIV - A viúva ou a mulher cujo casamento se desfez por ser nulo, ou ter sido anulado, , até dez meses depois do comêço da viuvez, ou da dissolução da sociedade conjugal, salvo se. antes de findo êsse prazo, der à luz algum filho".

O que se procura afastar é a "generationis incertitudo", a "confusão de sangue". Donde o prazo de dez mêses e sua automática redução na alternativa prevista, "in fine".

e) "XV - O tutor ou curador, e os seus descendentes, ascendentes, irmãos, cunhados ou sobrinhos, com a pessoa tutelada ou curatelada, enquanto não cessar a tutela ou curatela e não estiverem saldadas as respectivas contas, salvo permissão paterna ou materna, manifesta em escrito autêntico ou em testamento".

A não ser a intenção de evitar a coação moral do tutor ou curador ao tutelado ou curatelado, visa a lei, segundo Clóvis BEviláQUA, impedir que, pelo casamento, "se oculte a delapidação de bens confiados à administração do tutor ou curador". 
f) "XVI - O Juiz, ou Escrivão, e seus descendentes, ascendentes, irmãos, cunhados ou sobrinhos, com órfãos ou viúva da circunscrição territorial, onde um ou outro tiver exercício, salvo licença especial da autoridade judiciária superior".

E proíbição que atinge aos Juízes de Primeira Instância, sejam ou não, privativos de órgãos.

A segunda classe, prevista no parágrafo único do art. 258 , é a seguinte: anos."

"II - Do maior de sessenta anos e da maior de cinqüenta

"Essas pessoas já passaram da idade em que o casamento se realiza por impulso afetivo. Receiando que interêsses subalternos, ou especulações pouco escrupulosas, arrastem sexagenários e qüinquagenárias a enlaces inadequados ou inconvenientes, a lei põe um entrave às ambições, não permitindo que os seus haveres passem ao outro cônjuge por comunhão. Também não podem, como, em geral, todos aqueles a quem a lei impõe o regime da separação, fazer doações "inter vivos", um ao outro. De outro modo a lei seria, fàcilmente, burlada. E esta uma proposição que dispensa qualquer esclarecimento. É uma inferência que se impõe."

(Clóvis Beviláqua, "Código Civil dos Estados Unidos do Brasil Comentado”, 3. ${ }^{a}$ Ed. vol. II, pág. 168, nota n. ${ }^{\circ} 6$, ao art. 258).

Não há dúvida, pois, quanto à separação de bens protegida, inclusive, contra doações.

Pode sobreviver a dúvida, entretanto, quanto aos aquestos.

E dizer-se, neste particular, o mesmo que caberia em defesa da comunhão universal como regime legal:

"se o casamento é uma comunhão de vidas, nenhum regime corresponde melhor a essa atitude moral dos cônjuges."

"É a expressão mais perfeita da comunhão de vida estabelecida pelo matrimônio sôbre as bases da confiança plena", diz ENDEMANN.

Afinal de contas, trata-se de quinquagenário ou sexagenário e não de impúberes ou incapazes de qualquer espécie a que se devesse insistir em proporcionar curatela judicial ilimitada sob essa única forma, por vêzes embaraçosa e inócua, de irrestrita separação de bens.

Impõe-se, mesmo, ao exegeta, o cuidado de evitar "excessiva clemência e atenção" aos pressupostamente fracos e humildes para não incidir no êrro que tem paradigma no célebre MAgnaUd, o ultrapassado "bom juiz" de ChateauThierry, de que nos fala JoÃo CRUET no seu "A vida do Direito".

Não nos esqueçamos, sobretudo, quão várias são as classes e subclasses previstas no parágrafo único do art. 258, tornando inadequada a aplicação genérica à separação legal, dos argumentos advindos de uma classe apenas.

Aliás é, precisamente, o pai "do maior monumento jurídico da América Latina", Clóvis BeviláquA, o primeiro a dizer que "parece desarmônico êste dispositivo", num sistema em que se afasta a comunhão de bens em numerosos 
casos, como os do art. 258. Depois, se os cônjuges estipulam regime exclusivo da comunhão, o que se deve supôr é que não a querem, para os bens que, de futuro, the vierem".

"Como, porém, outra é a solução dada pelo Código Civil, cumpre que exprimam, claramente, a sua vontade, quanto aos adquiridcis, os nubentes que estipularem qualquer regime exclusivo da comunhão, pois no silêncio do contrato, entendem-se comuns, provenham de título oneroso ou gratuito."

"Aplica-se aos adquiridos o mesmo princípio, a que estão subordinados os bens trazidos para o casal: na falta de declaração em contrário, entendem-se comuns." (idem, op. cit.).

A terceira classe de hipóteses de separação de bens "ex vi legis" compreende não só os casamentos de órfãos de pai e mãe, como também, os de menores nos casos de suspensão ou perda do pátrio poder, por decisão judicial (artigos 394 e 395 ), embora efetuados com o consentimento do tutor.

Para os fins de esclarecimento do art. 259, esta classe de hipóteses é a mais elucidativa.

A quarta classe compreende os consórcios dos que dependerem de autorização judicial para casar, ou, mais pròpriamente, dos que recorrem ao Juiz, da recusa do consentimento paterno.

"Mas, para dificultar êsse recurso excepcional - diz Clóvis BEVILÁQUA - em atenção ao prestígio da autoridade dos progenitores, e porque, afinal, bem pode ser que os pais estejam com a razão, e não o Juiz, o Código permite o casamento mas sem comunhão. Se é uma afeição verdadeira que arrasta os jóvens ao matrimônio, essa restrição econômica, de modo algum, os embaraçará. Ela será, porém, suficiente para conter os impulsos meramente interesseiros" (BEvILÁQUA, op. cit. 3. ${ }^{a}$ Ed., pág. 168 ).

Reservamo-nos para opinar depois de longo exame da opinião dos doutos e de cada uma das hipóteses de separação legal porque, assim fazendo, já estávamos contribuindo para o mais amplo esclarecimento da questão.

Diante, aliás, da diversidade dos casos, de separação obrigatória, torna-se patente a impropriedade de certos argumentos levantados em favor da separação dos aquetsos.

Como admitir-se que um sistema que consagra o regime de bens como o preferido poderia admitir a separação dos aquestos como garantia ideal de órfãos, alternativa esta, implìcitamente, sustentada na interpretação restritiva do art. 259?

Forçoso será reconhecer que as cautelas do art. 258 restringem-se aos bens dos cônjuges no momento do enlace matrimonial.

Nem seria isenta de críticas a extensão de um tratamento, destinado a menores, a tôda a vida de um cidadão capaz.

Entendimento diverso parece apoiar-se, muito discutivelmente, em excessos rígidos e inflexíveis, não direi à letra da lei, mas a uma simples acepção de um têrmo - "contrato" — na mesma usado. 
Pontifica, a êsse respeito, pela autoridade grangeada com o seu trabalho sôbre "Regimes Matrimoniais", o Dr. OLIVEIRA CASTRO, negando, ao casamento, o caráter de contrato, nos casos de separação "ex-vi legis", porque assim estaria "aberrando do conceito básico de todo contrato".

Não tem razão entretanto, o tratadista, citado, aliás, por uma das mais fulgurantes expressões da cultura jurídica nacional - o Dr. ORozimbo NoNATO. Porque, hoje em dia, quando, realmente, a lei cada vez mais limita a liberdade contratual, atendendo a profundas razões sociológicas, não há que admirar-se de também fazê-lo nos casos presentes. Tanto mais que ela não compele ninguém ao contrato nupcial mas, no que se refere ao regime de bens, em certos e determinados casos, impõe o "da separação" a que corresponderia, por fôrça de lei, também, "a comunhão dos aquestos".

Diz, ainda, o Dr. OlIVEIRA CASTRo, que seria irrisório e ridículo o caráter coercitivo que emana, evidentemente, das medidas consignadas no Cod. Civil, art. 258, parágrafo único, se a separação obrigatória não fôsse extensível aos bens futuramente adquiridos pelos cônjuges". Mais uma vez, discordamos do ilustre autor; ridículo seria que a lei não proibisse (como proibe) doações de um cônjuge ao outro. Tanto que, apezar disso, registram-se tentativas nêsse sentido, às quais a Justiça tem negado, terminantemente, e sem discrepância, existência jurídica.

Muito diferente é o caso da comunhão dos aquestos, defensável com os mesmos fundamentos da "comunhão universal" e, especialmente, considerado o pressuposto da conjugação de esforços de que êles decorrem. Tanto esta relação é convincente que o Min. Orozimbo Nonato que, em 1947, dizia que "quando muito poder-se-ia consentir na existência de "societas specialis" de fato e não uma "societas omnium bonorum" (Cf. Rev. Forense, 1948, n. ${ }^{\circ}$ 545, pág. 109) chegava, em 1948 a argumentar:

"Possível é que ocorra, então, uma sociedade "ex- factis et rebus"; mas essa sociedade não se confunde com a comunhão conjugal, que é "sui generis" e tem características próprias que a extremam da sociedade."

De nossa parte, nada vemos, de prático, em tal solução. Além do mais, a entender-se como peremptória, definitiva, absoluta a separação de bens, incoerente seria admitir-se, agora, tal espécie de sociedade que apenas considerasse a contribuição material da mulher, desprezando o valor inestimável daquela que decorre das atividades domésticas e, precisamente, justificam a solução dada pelo Código Civil. Tanto mais, como lembra Costa Manso, quando se considera a regra do art. 1.376 , do Código Civil, segundo a qual, no silêncio do contrato, presumem-se iguais as entradas.

Ponderados, pois, os argumentos favoráveis à comunicabilidade dos aquestos nos regimes de separação "ex vi legis" e confrontados os mesmos, cuidadosamente, com as diversas hipóteses em que ela ocorre, não vemos como negar-lhe procedência completa. leiro.

E a única solução em harmonia com a sistemática do Código Civil Brasi- 